\title{
PENGARUH MOTIVASI BERWIRAUSAHA, PENGENDALIAN DIRI, DAN LINGKUNGAN KELUARGA TERHADAP NIAT BERWIRAUSAHA
}

\author{
Putu Talitha Amadea ${ }^{1}$ \\ I Gede Riana ${ }^{2}$
}

\author{
${ }^{1,2}$ Fakultas Ekonomi dan Bisnis Universitas Udayana, Bali, Indonesia \\ email: talitha_amadea@yahoo.com
}

\begin{abstract}
ABSTRAK
Tujuan dari penelitian ini adalah untuk menguji pengaruh motivasi berwirausaha, pengendalian diri, dan lingkungan keluarga terhadap Niat Berwirausaha Mahasiswa Universitas Udayana. Penelitian ini dilakukan pada mahasiswa wirausaha Universitas Udayana 2018. Jumlah sampel dalam penelitian ini sebanyak 207 responden. Teknik pengambilan sampel yaitu sampling jenuh. Pengumpulan data diperoleh dari hasil penyebaran kuesioner secara langsung maupun online kepada mahasiwa wirausaha. Analisis data dalam penelitian ini menggunukan analisis regresi linier berganda . Hasil peneltitian ini menunujukkan bahwa motivasi berwirausaha berpengaruh positif dan signifikan terhadap niat berwirausaha, pusat kendali diri berpengaruh positif dan signifikan terhadap niat berwirausaha, lingkungan keluarga berpengaruh positif dan signifikan terhadap niat berwirausaha. Universitas Udayana sebaiknya lebih sering mengadakan seminar tentang kewirausahaan agar semakin banyak mahasiswa yang termotivasi untuk menjadi wirausaha muda.
\end{abstract}

Kata kunci: motivasi berwirausaha, pusat kendali diri, lingkungan keluarga, niat berwirausaha

\begin{abstract}
The purpose of this study was to examine the effect of entrepreneurial motivation, locus of control, and family environment on the entrepreneurial intention of Udayana University students. This research was conducted on entrepreneurial students of Udayana University 2018. The number of samples in this study were 207 respondents. The sampling technique is saturated sampling. Data collection was obtained from the results of distributing questionnaires directly or online to entrepreneurial students. Analysis of the data in this study uses multiple linear regression analysis. The results of this study indicate that entrepreneurship motivation has a positive and significant effect on entrepreneurial intentions, self-control center has a positive and significant effect on entrepreneurial intentions, the family environment has a positive and significant effect on entrepreneurial intentions. Udayana University should hold more frequent seminars on entrepreneurship so that more and more students are motivated to become young entrepreneurs.

Keywords: entrepreneurship motivation, self-control center, family environment, entrepreneurial intentions
\end{abstract}




\section{PENDAHULUAN}

Seiring dengan meningkatnya jumlah penduduk Indonesia, yang saat ini sudah mencapai lebih dari 269 juta jiwa (Badan Pusat Statistik, 2019), bertambah pula kebutuhan pangan, papan, lapangan kerja, dan pendidikan yang harus dipenuhi. Memasuki persaingan global saat ini, masalah pengangguran dan kemiskinan merupakan masalah klasik yang menghinggapi negara-negara berkembang termasuk Indonesia. Pengangguran dan kemiskinan masih menjadi permasalahan di Indonesia. Pengangguran dan kemiskinan terjadi karena perbandingan antara jumlah penawaran kesempatan kerja tidak sebanding dengan jumlah lulusan atau penawaran tenaga kerja baru di segala level pendidikan (Saiman, 2009). Setiap tahun beratus-ratus atau berjuta-juta orang ingin bekerja atau mendapatkan pekerjaan. Mereka mencoba menjadi karyawan di sebuah instansi yang dirasa sesuai dengan kemampuan yang dimiliki. Hanya sedikit yang berpikir untuk menciptakan lapangan pekerjaan. Mereka berharap menjadi karyawan, pegawai, buruh atau menjual tenaganya begitu saja sekadar mengharapkan imbalan jasa.

McClelland dalam Silvia (2013), mengemukakan bahwa suatu negara dapat maju apabila dua persen dari total penduduk suatu negara berprofesi sebagai entrepreneur. (Suharti \& Sirine, 2011) menyatakan jumlah wirausahawan muda di Indonesia hanya sekitar 0,18 persen dari total penduduk masih tertinggal jauh dibandingkan negara-negara maju seperti Amerika yang mencapai 11,5 persen maupun Singapura yang memiliki 7,2 persen wirausahawan muda dari total penduduknya. Hal ini akan teratasi apabila orang tersebut mempunyai minat untuk menciptakan lapangan pekerjaan sendiri yaitu dengan bekerja sesuai keterampilandan pengetahuan yang dimiliki, tidak usah mengandalkan untuk mendapatkanpekerjaan dari orang lain atau bekerja pada instansi pemerintah.

Jumlah wirausaha di suatu negara kerap dianggap sebagai indikator kemajuan. Patokannya minimal $2 \%$ dari jumlah penduduk harus berprofesi sebagai wirausaha. Indonesia memiliki total penduduk sebanyak 269 juta jiwa, dengan jumlah penduduk 269 juta jiwa, negeri ini paling kurang harus memiliki 5 juta jiwa wirausaha. Dibandingkan dengan negara tetangga, harus diakui, kita kalah jumlah. Singapura ada di angka 7\%, Malaysia 5\%, Thailand 4,5\%, dan Vietnam 3,3\%. Amerika dan Jepang sudah melejit jauh. Sepuluh persen warganya terjun di dunia bisnis. Pendidikan Kewirausahaan di Lingkup Perguruan Tinggi Pendidikan kewirausahaan sudah banyak digalakkan di jenjang Perguruan Tinggi di Indonesia, tak hanya di jurusan bisnis, di prodi pendidikan pun sudah dilaksanakan. Seminar kewirausahaan, ekspo kewirausahaan, bahkan pendanaan proposal kewirausahaan mahasiswa oleh pihak Perguruan Tinggi menjadi hot trend belakangan ini. Belum lagi dukungan pemerintah yang terus berupaya untuk semakin memudahkan lingkungan bisnis agar kondusif bagi pelaku usaha, seperti menjanjikan kemudahan akses terhadap permodalan/pinjaman bank tanpa dibebani agunan kredit melalui program Kredit Usaha Rakyat (KUR) dan program-program lain berupa pelatihan ketrampilan, pendanaan Program Kreativitas Mahasiswa (PKM) dan lain sebagainya semakin mendukung usaha muda dan usaha baru untuk bergerak. 
Menilik dukungan keadaan yang demikian, mahasiswa akan semakin dapat mengepakkan sayap di bidang kewirausahaan.

Niat untuk berwirausaha mahasiswa di Universitas Udayana masih sedikit. Jumlah mahasiswa wirausaha baru Universitas Udayana pada tahun 2018 berdasarkan Direktori Mahasiswa Wirausaha Universitas Udayana (2018) hanya mencapai 207 orang mahasiswa padahal Universitas Udayana memiliki banyak mahasiswa dimasing-masing fakultasnya. Jika dikelompokkan berdasarkan fakultas asal mahasiswa, penciptaan wirausaha baru tertinggi diperoleh Fakultas Ekonomi dan Bisnis dengan capaian 52 mahasiswa, lalu dilanjutkan dengan Fakultas Ilmu Budaya yang mencapai 46 mahasiswa, dan Fakultas Pertanian yang menduduki tempat ketiga dengan capaian 38 mahasiswa, sedangkan Fakultas Peternakan, Fakultas Kedokteran Hewan serta Fakultas Kelautan dan Perikanan berada pada peringkat terbawah dikarenakan tidak menghasilkan wirausaha baru pada tahun 2018. Data wirausaha baru Universitas Udayana Tahun 2018 berdasarkan fakultas asal tersaji dalam Tabel 1.

Tabel 1.

Data jumlah Wirausaha Baru Universitas Udayana Tahun 2018 (dalam satuan orang)

\begin{tabular}{clc}
\hline No & \multicolumn{1}{c}{ Nama Fakultas } & Jumlah \\
\hline 1 & Fakultas Ekonomi dan Bisnis & 52 \\
2 & Fakultas Ilmu Budaya & 46 \\
3 & Fakultas Pertanian & 38 \\
4 & Fakultas Tekonologi Pertanian & 17 \\
5 & Fakultas Kedokteran & 16 \\
6 & Fakultas Teknik & 11 \\
7 & Fakultas Ilmu Sosial dan Politik & 9 \\
8 & Fakultas Hukum & 8 \\
9 & Fakultas MIPA & 7 \\
10 & Fakultas Pariwisata & 3 \\
11 & Fakultas Peternakan Total & 0 \\
12 & Fakultas Kedokteran Hewan & 0 \\
13 & Fakultas Kelautan dan Perikanan $\quad$ Total & 0 \\
& & 207 \\
\hline
\end{tabular}

Sumber: Direktori Mahasiswa Wirausaha Universitas Udayana (2018)

Chimucheka (2013), menyatakan bahwa salah satu faktor pendorong pertumbuhan kewirausahaan di suatu negara terletak pada peranan universitas melalui penyelenggaraan pendidikan kewirausahaan. Menumbuhkan jiwa kewirausahaan para mahasiswa perguruan tinggi dipercaya merupakan alternatif untuk mengurangi tingkat pengangguran, karena para sarjana diharapkan dapat menjadi wirausahawan muda terdidik yang mampu merintis usahanya sendiri karena dunia bisnis masa kini dan masa depan lebih mengandalkan knowledge dan intelectual capital, maka agar dapat menjadi daya saing bangsa, pengembangan wirausaha muda perlu diarahkan pada kelompok muda terdidik (Azwar, 2013). Rasli et al. (2013) mengatakan niat kewirausahaan adalah suatu pikiran yang mendorong individu untuk menciptakan usaha. Niat berwirausaha didefinisikan sebagai tendensi keinginan individu untuk melakukan tindakan wirausaha dengan menciptakan produk baru melalui peluang bisnis dan pengambilan risiko (Ramayah 
\& Harun, 2005). Individu yang mempunyai minat pada suatu kegiatan akan melakukannya dengan giat daripada kegiatan yang tidak diminatinya.

Peran motivasi dalam berwirausaha dapat dianalogikan sebagai bahan bakar penggerak mesin. Motivasi berwirausaha yang memadai akan mendorong untuk berperilaku aktif dalam berwirausaha, tetapi motivasi yang terlalu kuat justru dapat berpengaruh negatif terhadap keefektifan usaha tersebut (Aidha, 2016). Kebanyakan orang yang berhasil di dunia ini mempunyai motivasi yang kuat yang mendorong tindakan-tindakan mereka. Motivasi untuk mengembangkan usaha baru diperlukan bukan hanya oleh rasa percaya diri dalam hal kemampuannya untuk berhasil, namun juga oleh kemampuannya dalam mengakses informasi mengenai peluang kewirausahaan. Peran motivasi dalam berwirausaha dapat dianalogikan sebagai bahan bakar penggerak mesin. Kebanyakan orang yang berhasil di dunia ini mempunyai motivasi yang kuat yang mendorong tindakan-tindakan mereka. Motivasi untuk mengembangkan usaha baru diperlukan bukan hanya oleh rasa percaya diri dalam hal kemampuannya untuk berhasil, namun juga oleh kemampuannya dalam mengakses informasi mengenai peluang kewirausahaan. Penelitian yang dilakukan oleh Owoseni (2014), menyatakan bahwa motivasi berwirausaha secara signifikan berpengaruh positif terhadap niat berwirausaha. Hasil penelitian lainnya yang ditemukan oleh Kumalasari (2013) mengatakan bahwa motivasi berpengaruh positif dan signifikan terhadap niat berwirausaha.

Faktor yang berpengaruh selanjutnya adalah locus of control. Wiriani et al. (2013) menyatakan locus of control terdiri dari dua konstruk yaitu internal dan eksternal, dimana internal locus of control apabila seseorang meyakini bahwa apa yang terjadi selalu berada dalam kontrolnya dan dia selalu mengambil peran serta bertanggung jawab dalam setiap pengambilan keputusan, sedangkan external locus of control apabila seseorang meyakini bahwa kejadian dalam hidupnya berada diluar kontrolnya. Penelitian Ayodele (2013), menemukan bahwa locus of control berpengaruh positif terhadap niat berwirausaha. Penelitian Uddin \& Bose (2012), juga menemukan adanya pengaruh positif locus of control terhadap niat berwirausaha.

Hisrich et al. (2008) menemukan bahwa dari 725 wirausahawan yang diteliti mempunyai orang tua atau ayah yang relatif dekat dengan dunia kewirausahaan. Sarwoko (2011) menyatakan mahasiswa yang latar belakang keluarga atau saudaranya berwirausaha memiliki niat kewirausahaan yang lebih besar dibandingkan mahasiswa yang keluarga atau saudaranya tidak berwirausaha dimana mahasiswa yang keluarganya memiliki usaha telah memiliki pengalaman berwirausaha, sehingga dapat merencanakan karir berwirausaha di masa depan sebagai pilihan hidup. Dewi \& Mulyatiningsih (2013) dalam penilitian menemukan bahwa lingkungan keluarga efektif memberikan pengalaman pendidikan kewirausahaan. Gallyn (2011) menyatakan bahwa variabel lingkungan keluarga mempunyai pengaruh positif terhadap niat berwirausaha.Hal ini menunjukkan bahwa pengalaman usaha dari keluarga akan memberikan pengalaman secara tidak langsung kepada seseorang untuk memiliki minat berwirausaha, karena minimal seseorang atau mahasiswa memiliki pengetahuan bagaimana menjalankan usaha, bagaimana menghadapi masalah dalam usaha, bagaimana memasarkan produk atau jasa, bagaimana mengakses modal dan sebagainya. Lingkungan keluarga yang dapat mempengaruhi seseorang untuk menjadi wirausahadapat dilihat dari segi 
faktor pekerjaan orang tua.Pekerjaan orang tua sering kali terlihat bahwa ada pengaruh dari orang tua yang bekerja sendiri dan memiliki usaha sendiri maka cenderung anaknya akan menjadi pengusaha Ardiyani \& Kusuma (2016).

Penelitian sebelumnya yang dilakukan oleh (Aldino, 2011) menunjukan bahwa motivasi berpengaruh signifikan terhadap niat berwirausaha.Hasil penelitian lainnya yang ditemukan oleh Kumalasari (2013)mengatakan bahwa motivasi berpengaruh positif dan signifikan terhadap niat berwirausaha.Penelitian yang dilakukan oleh Owoseni (2014), menyatakan bahwa motivasi berwirausaha secara signifikan berpengaruh positif terhadap niat berwirausaha. Farouk dan Ikram (2014) menyatakan bahwa motivasi berwirausaha berpengaruh positif dan signifikan terhadap niat berwirausaha. Kusuma \& Warmika (2016) menyatakan bahwa motivasi berwirausaha berpengaruh positif signifikan terhadap niat berwirausaha. Berdasarkan penelitian tersebut, rumusan hipotesis yang digunakan yaitu:

$\mathrm{H}_{1}$ : Motivasi Berwirausaha berpengaruh positif dan signifikan terhadap niat berwirausaha

Penelitian Dinis et al. (2013), mengungkapkan bahwa locus of control berpengaruh positif dan signifikan terhadap niat berwirausaha. Penelitian Ayodele (2013) juga mengatakan bahwa locus of control berpengaruh positif terhadap niat berwirausaha. Uddin \& Bose (2012) juga menemukan pengaruh positif dari locus of control terhadap minat berwirausaha. Adnyana \& Purnami (2016) mengatakan bahwa locus of control berpengaruh positif dan signifikan terhadap niat berwirausaha. Bustan (2014) yang menemukan bahwa variabel locus of control mempengaruhi niat mahasiswa Politeknik Sriwijaya untuk berwirausaha. Berdasarkan penelitian tersebut, rumusan hipotesis yang digunakan yaitu:

$\mathrm{H}_{2}$ : Pengendalian Diri berpengaruh positif dan signifikan terhadap niat berwirausaha

Sarwoko (2011) menemukan bahwa mahasiswa yang latar belakang keluarganya memiliki usaha ternyata memiliki niat kewirausahaan yang lebih besar dibandingkan mahasiswa yang keluarganya tidak memiliki usaha. Rasyid (2015) menyatakan bahwa pengalaman orang tua ialah dorongan berupa pendapat terhadap sesuatu berdasarkan pengetahuan dan pengalaman yang dimilikinya yang berguna untuk memberikan masukan sehingga nanti dapat mempengaruhi keputusan yang akan diambil. Suharti \& Sirine (2011) menyatakan lingkungan keluarga berpengaruh positif signifikan terhadap niat berwirausaha. Semakin kondusif lingkungan keluarga disekitarnya maka akan semakin mendorong seseorang untuk menjadi seorang wirausaha. Apabila lingkungan keluarga mendukung maka seseorang akan semakin tinggi niatnya untuk menjadi wirausaha. Ardiyani \& Kusuma (2016) menyatakan lingkungan keluarga berpengaruh positif terhadap niat berwirausaha. Hasil penelitian dari Hutagalung et al. (2017) juga menyatakan lingkungan keluarga berpengaruh positif signifikan terhadap niat berwirausaha. Berdasarkan penelitian tersebut, rumusan hipotesis yang digunakan yaitu:

$\mathrm{H}_{3}$ : Lingkungan Keluarga berpengaruh positif dan signifikan terhadap niat berwirausaha 
McClelland (1965) menyiratkan bahwa ketika individu menetapkan target mereka mengenai kebutuhan yang lebih tinggi, maka orang-orang akan lebih mudah menyelesaikan pekerjaan yang memerlukan usaha dari diri sendiri, dan lebih mampu melakukan pekerjaan yang memerlukan tanggung jawab tinggi serta akan mendapatkan hasil atau umpan balik dari kerja kerasnya. McClelland (1965) menyatakan bahwa golongan wiraswastawan yang memiliki Need for Achivement atau motif berprestasi yang tinggi ialah para wiraswastawan yang berhasil. Motif berprestasi yaitu kebutuhan untuk memperoleh suatu hasil atau prestasi yang lebih, dan melakukan sesuatu dengan lebih efisien, lebih cepat daripada yang pernah dibuat sebelumnya. Selain itu memiliki kebijakan pribadi, berkebijakan sosial dan perhatian pada kesejahteraan orang lain secara umum. Pendapat dan studi pengantar yang telah dikemukakan menyatakan bahwa motif berprestasi sangat penting dalam mewujudkan kewiraswastaan dikalangan mahasiswa. Pada kenyataannya mahasiswa memang sudah memiliki kriteria tersebut, tetapi intensi berwiraswastanya kurang di kalangan mahasiswa itu sendiri. Mahasiswa lebih fokus pada keinginan mendapat pekerjaan pada badan usaha milik pemerintah atau swasta setelah menyelesaikan pendidikan, artinya bekerja pada orang lain.

Wardoyo (2012) mendefinisikan kebutuhan akan prestasi sebagai keinginan individu untuk menyelesaikan sesuatu hal yang sulit, dapat mengungguli, dan melakukan lebih baik dari pada orang lain. Kebutuhan akan berprestasi juga didefinisikan Habaragoda (2013) sebagai cerminan dari orientasi yang kuat terhadap tujuan dan obsesi yang besar terhadap pekerjaan atau tugas yang harus dilakukan. Ogunleye \& Osagu (2014) kebutuhan akan prestasi adalah kecenderungan untuk memilih dan bertahan pada suatu kegiatan dalam mencapai keberhasilan atau kesempatan maksimum dan kepuasan akan prestasi sendiri tanpa risiko kegagalan.

Baum et al. (2007) menjelaskan bahwa motivasi dalam kewirausahaan meliputi motivasi yang diarahkan untuk mencapai tujuan kewirausahaan, seperti tujuan yang melibatkan pengenalan dan eksploitasi terhadap peluang bisnis. Pujiastuti (2013) mengatakan di dalam menjalankan entrepreneurship harus memiliki sebuah motivasi yang kuat, motivasi yang dimaksud adalah suatu proses dimana seseorang bertingkah laku mencapai tujuan untuk memuaskan kebutuhannya. Motivasi untuk mengembangkan usaha baru juga diperlukan adanya percaya diri, kreativitas, keterampilan, mempunyai jiwa kepemimpinan, berorientasi pada masa depan, serta kemampuan untuk mengakses informasi mengenai peluang kewirausahaan. Kebanyakan orang yang berhasil di dunia ini memiliki motivasi kuat yang bisa mendorong tindakan-tindakan mereka.

Motivasi menjadi entrepreneur adalah sesuatu yang melatarbelakangi atau mendorong seseorang melakukan aktivitas dan memberi energi yang mengarah pada pencapaian kebutuhan, memberi kepuasan ataupun mengurangi ketidakseimbangan dengan membuka suatu usaha atau bisnis (Tama, 2010). Dalam aspek lain, keberanian seseorang untuk mendirikan usaha sendiri (berwirausaha) sering kali terdorong oleh motivasi dari guru atau dosennya yang mengampu mata pelajaran atau mata kuliah berkewirausahaan yang praktis dan menarik, sehingga dapat membangkitkan niat siswa untuk mulai mencoba berwirausaha (Saiman, 2009). 
Venesaar et al. (2016) menjelaskan bahwa motivasi seseorang menjadi wirausaha dibagi dalam tiga dimensi, yaitu; Ambition for freedom (aktivitas lebih bebas, memiliki usaha sendiri, menjadi lebih dihormati, terdepan dalam menerapkan ide baru, mengembangkan hobi dalam bisnis), Self-realization (Memperoleh posisi yang lebih baik di masyarakat, Merasakan tantangan, Memotivasi dan memimpin orang lain, melanjutkan tradisi keluarga, Mengimplementasikan ide atau berinovasi, mengikuti orang lain), Pushing factors (Kehilangan pekerjaan, Memperoleh pendapatan yang lebih baik, Tidak puas dengan pekerjaan). Peran motivasi seseorang sangat penting dalam berwirausaha, karena motivasi dapat menentukan sejauh mana keberhasilan dapat diraih. Motivasi juga menggambarkan suatu keadaan yang dapat mempengaruhi berbagai aspek dari proses kewirausahaan.

Locus of control pertama kali dikemukakan oleh Rotter pada tahun 1966 seorang ahli pembelajaran social. (Rotter, 1969) mendefinisikan locus of control sebagai ekspektasi dari kontrol internal atau eksternal yang dirasakan atau sejauh mana seorang individu memandang peristiwa sebagai sesuatu yang bergantung pada perilakunya sendiri. Locus of control merupakan salah satu variabel kepribadian (personality), yang didefinisikan sebagai keyakinan individu terhadap mampu atau tidaknya mengontrol nasib sendiri. Individu yang memiliki keyakinan bahwa suatu kejadian yang terjadi dalam kehidupannya berada dibawah kontrol dirinya, maka individu tersebut memiliki internal locus of control. Individu yang memiliki keyakinan bahwa lingkunganlah yang mempunyai kontrol terhadap kejadian yang terjadi didalam kehidupannya dikatakan individu tersebut memiliki external locus of control (Wiriani et al., 2013).

Konsep Locus of control didasarkan pada teori belajar sosial. Kustini (2005) menyatakan bahwa Locus of control adalah salah satu aspek kepribadian yang dimiliki oleh setiap individu, yang pada dasarnya menunjukkan pada keyakinan individu mengenai sumber penyebab dari peristiwa-peristiwa yang terjadi pada dirinya. Robbins \& Judge (2006) mengungkapkan Locus of control adalah tingkat di mana individu yakin bahwa mereka adalah penentu nasib mereka sendiri.Teori ini menyatakan bahwa pilihan-pilihan yang dijatuhkan individu berasal dari berbagai potensi perilaku yang mungkin atau tersedia baginya.

Locus of control merupakan suatu konsep yang menunjuk pada keyakinan individu mengenai peristiwa-peristiwa yang terjadi dalam hidupnya. Myers \& Spencer (2013), menyatakan bahwa locus of control adalah persepsi tentang bagaimana seseorang dapat mengendalikan takdirnya. Robbins \& Judge (2007) juga mendefinisikan locus of control sebagai tingkatan kepercayaan seseorang dalam mengendalikan takdirnya.

Locus of control mengarah pada suatu ukuran yang menunjukkan bagaimana seseorang memandang kemungkinan adanya hubungan antara perbuatan yang dilakukan dengan akibat atau hasil yang diperoleh. Locus of control adalah persepsi seseorang terhadap keberhasilan ataupun kegagalannya dalam melakukan berbagai kegiatan dalam hidupnya. 
Lingkungan Keluarga adalah kelompok masyarakat terkecil yang terdiri dari ayah, ibu, anak, dan anggota keluarga yang lain. Lingkungan keluarga menurut Lestari \& Wijaya (2012) adalah jumlah semua benda hidup dan mati serta seluruh kondisi yang ada di dalam kelompok sosial kecil tersebut, yang terdiri atas ayah, ibu dan anak yang mempunyai hubungan sosial karena adanya ikatan darah, perkawinan dan atau adopsi. Niat berwirausaha akan terbentuk apabila keluarga memberikan pengaruh positif terhadap minat tersebut, karena sikap dan aktifitas sesama anggota keluarga saling mempengaruhi baik secara langsung maupun tidak langsung.

Mahasiswa yang latar belakang keluarganya berwirausaha memiliki niat yang lebih tinggi untuk menjadi seorang wirausaha. Hal ini menunjukkan bahwa pengalaman usaha dari keluarga akan memberikan pengalaman secara tidak langsung kepada seseorang untuk memiliki minat berwirausaha, karena minimal seseorang tersebut memiliki pengetahuan bagaimana menjalankan usaha, bagaimana menghadapi masalah dalam usaha, bagaimana menghadapi masalah dalam usaha, bagaimana memasarkan produk atau jasa, bagaimana mengakses modal dan sebagainya (Sarwoko, 2011). Mahasiswa yang memiliki orang tua yang berwirausaha memiliki niat kewirausahaan yang lebih tinggi dibanding mahasiswa yang orang tuanya tidak berwirausaha (Suharti \& Sirine, 2011).

Kewirausahaan muncul sejak tahun 1940an dan 1950an, yang ditandai dengan terpublikasinya penelitian yang dilakukan oleh Joseph Scumpter dan Alferd Chandler dalam jurnal yang berjudul Explorations in Enterpreneurship History. Kewirausahaan adalah kemampuan kreatif dan inovatif yang dijadikan dasar, kiat dan sumber daya untuk mencari peluang menuju sukses(Suryana, 2008). Kemampuan menciptakan memerlukan adanya kreativitas dan inovasi yang terus menerus untuk menemukan sesuatu yang berbeda dari yang sudah ada sebelumnya (Kasmir, 2010). Nursito \& Jati (2013) menyatakan niat kewirausahaan adalah keadaan berfikir secara langsung dan mengarahkan perilaku individu kearah pengembangan dan implementasi konsep bisnis yang baru. Wijaya \& Tanumihardja (2014) niat berwirausaha yaitu kesediaan untuk bekerja keras dan tekun untuk mencapai kemajuan suatu usaha, kesediaan untuk menanggung berbagai macam risiko berkaitan dengan tindakan yang dilakukan, bersedia menempuh jalur dan cara baru dan kesediaan untuk belajar dari pengalaman.

Slameto (2010) menyatakan bahwa "Niat adalah suatu rasa lebih suka dan rasa ketertarikan pada suatu hal atau aktivitas, tanpa ada yang menyuruh".Niat berwirausaha siswa dapat tumbuh dan berkembang apabila siswa mempunyai ketertarikan pada bidang wirausaha.Ketertarikan ini biasanya muncul karena siswa menyukai kegiatan wirausaha atau sudah terbiasa dengan kegiatan berwirausaha.Ketertarikan untuk berwirausaha juga harus di dorong dengan adanya kehendak untuk melakukan kegiatan wirausaha agar kegiatan berwirausaha dapat berjalan dengan baik. Niat berwirausaha diukur dengan skala entrepreneurial intention dengan indikator memilih jalur usaha daripada bekerja dengan orang lain, memilih karir sebagai wirausahawan, membuat membuat perencanaan untuk memulai usaha, meningkatkan status sosial (harga diri) sebagai wirausaha dan mendapatkan pendapatan yang lebih baik. Niat berwirausaha merupakan pemusatan perhatian pada wirausaha karena adanya rasa suka dan disertai keinginan 
mempelajari, mengetahui dan membuktikan lebih lanjut terhadap wirausaha (Mustofa, 2014).

Praswati (2014) menyatakan niat berwirausaha dipengaruhi oleh faktor internal dan eksternal. Faktor internal yaitu kepribadian, persepsi, motivasi, dan pembelajaran atau sikap.Faktor eksternal adalah keluarga, teman, tetangga dan lainlain. Niat berwirausaha pada akhirnya merupakan suatu pikiran yang mengarahkan tindakan individu untuk melakukan atau menciptakan usaha baru yang kreatif dan unik. Suatu tindakan yang diawali dengan niat akan memiliki kesiapan dan kemajuan yang lebih baik dalam menjalankan suatu usaha dibandingkan dengan seseorang yang tidak memiliki niat untuk memulai usaha.

\section{METODE PENELITIAN}

Penelitian ini merupakan penelitian asosiatif (hubungan), dengan tujuan menganalisis pengaruh antara variabel bebas dan variabel terikat. Penelitian ini di desain untk mencari pengaruh motivasi berwirausaha $\left(\mathrm{X}_{1}\right)$, Locus Of Control $\left(\mathrm{X}_{2}\right)$ dan lingkungan keluarga $\left(\mathrm{X}_{3}\right)$ terhadap niat berwirausaha $(\mathrm{Y})$. Penelitian ini bertempat di Universitas Udayana. Lokasi ini dipilih karena ditemukan adanya mahasiswa yang sudah memiliki usaha. Obyek dari penelitian ini adalah Motivasi berwirausaha, pengendalian diri (locus of control), lingkungan keluarga dan niat berwirausaha.

Populasi dalam penelitian ini adalah di mahasiswa wirausaha S1 Universitas Udayana yang berjumlah 207 orang. Sampel adalah bagian dari jumlah dan karakteristik yang dimiliki oleh populasi tersebut, sedangkan ukuran sampel adalah banyaknya objek psikologis yang merupakan anggota sampel. Teknik sampling yang digunakan dalam penelitian ini adalah sampling jenuh, dikarenakan seluruh populasi pada penelitian ini digunakan sebagai responden.

Analisis regresi linier berganda digunakan untuk mengetahui hubungan antara dua variabel bebas atau lebih terhadap variabel terikat untuk membuktikan ada atau tidaknya hubungan kausal antara dua variabel bebas atau lebih dengan satu variabel trikat. Persamaan regresi linier berganda dirumuskan sebagai berikut:

$$
\mathrm{Y}=\mathrm{a}+\mathrm{b}_{1} \mathrm{X}_{1}+\mathrm{b}_{2} \mathrm{X}_{2}+\mathrm{b}_{3} \mathrm{X}_{3}+\mathrm{e}
$$

Dimana:

$$
\begin{array}{ll}
\mathrm{Y} & =\text { Niat berwirausaha } \\
\mathrm{a} & =\text { Bilangan konstan } \\
\mathrm{b}_{1}, \mathrm{~b}_{2}, \mathrm{~b}_{3} & =\text { Koefisien regresi } \\
\mathrm{X}_{1} & =\text { Motivasi Berwirausaha } \\
\mathrm{X}_{2} & =\text { Locus of control } \\
\mathrm{X}_{3} & =\text { Lingkungan Keluarga } \\
\mathrm{e} & =\text { error }
\end{array}
$$




\section{HASIL DAN PEMBAHASAN}

Responden penelitian ini digambarkan secara umum mengenai karakteristik dilihat dari jenis kelamin dan 10 fakultas yang berisi mahasiwa wirausaha di Universitas Udayana. Jumlah responden yang digunakan dalam penelitian ini sebanyak 207 orang. Pengelompokan responden dapat dilihat pada Tabel 3.

Tabel 3.

Karakteristik Responden

\begin{tabular}{cllcc}
\hline NO Karakteristik & \multicolumn{1}{c}{ Klasifikasi } & $\begin{array}{c}\text { Jumlah } \\
\text { Responden } \\
\text { (Mahasiswa) }\end{array}$ & $\begin{array}{c}\text { Persentase } \\
\text { Responden } \\
\text { (\%) }\end{array}$ \\
\hline \multirow{2}{*}{1 Jenis Kelamin } & Laki-Laki & 93 & 44,93 \\
& & Perempuan & 114 & 55,07 \\
& & Jumlah & $\mathbf{2 0 7}$ & $\mathbf{1 0 0}$ \\
& & Fakultas Ekonomi dan Bisnis & 52 & 25,15 \\
& & Fakultas Ilmu Budaya & 46 & 22,24 \\
& & Fakultas Pertanian & 38 & 18,35 \\
& & Fakultas Teknologi Pertanian & 17 & 8,21 \\
& & Fakultas Kedokteran & 16 & 7,72 \\
& & Fakultas Teknik & 11 & 5,31 \\
& & & & \\
& & Fakultas Ilmu Sosial dan Politik & 9 & 4,34 \\
& & Fakultas Hukum & 8 & 3,86 \\
& & Fakultas MIPA & 7 & 3,38 \\
& & Fakultas Pariwisata & 3 & 1,44 \\
& & Jumlah & $\mathbf{2 0 7}$ & $\mathbf{1 0 0}$ \\
\hline
\end{tabular}

Sumber: Data primer, 2019

Berdasarkan Tabel 3. Penglompokan responden berdasarkan jenis kelamin menunjukkan bahwa jumlah responden laki-laki dengan persentase sebesar 44,93 persen (93 mahasiswa) sedangkan responden perempuan dengan persentase sebesar 55,07 persen (114 mahasiswa). Selain itu penglompokan responden berdasarkan fakultas terdapat 10 fakultas. Mayoritas responden adalah mahasiswa fakultas ekonomi dan bisnis dengan persentase 25,15 persen (52 mahasiswa). Terendahnya pada Fakultas Pariwisata dengan persentase 1,44 persen ( 3 mahasiswa).

Instrumen penelitian dapat dikatakan valid apabila pernyataan dalam kuesioner mampu mengungkapkan sesuatu yang akan diukur oleh kuesioner tersebut. Pengujian validitas dilakukan dengan menghitung Pearson Correlation. Suatu instrument dikatakan valid apabila r Pearson Correlation terhadap skor total diatas 0,30. Berikut disajikan Tabel 4. hasil uji validitas.

Hasil uji validitas Tabel 4. menunjukkan bahwa seluruh instrumen dalam penelitian memiliki angka Pearson Correlation yang lebih besar dari angka 0,30. Hal ini menunjukkan bahwa butir-butir pernyataan dalam instrument penelitian tersebut valid dan layak digunakan sebagai instrumen penelitian. 
Tabel 4.

Hasil Uji Validitas Instrumen Penelitian

\begin{tabular}{|c|c|c|c|c|}
\hline No. & Variabel & Indikator & $\begin{array}{c}\text { Pearson } \\
\text { Correlation }\end{array}$ & Keterangan \\
\hline \multirow[t]{4}{*}{1.} & Motivasi Berwirausaha $\left(\mathrm{X}_{1}\right)$ & $\mathrm{X}_{1.1}$ & 0,904 & Valid \\
\hline & & $\mathrm{X}_{1.2}$ & 0,898 & Valid \\
\hline & & $\mathrm{X}_{1.3}$ & 0,824 & Valid \\
\hline & & $\mathrm{X}_{1.4}$ & 0,754 & Valid \\
\hline \multirow[t]{4}{*}{2.} & Locus of Control $\left(\mathrm{X}_{2}\right)$ & $\mathrm{X}_{2.1}$ & 0,899 & Valid \\
\hline & & $\mathrm{X}_{2.2}$ & 0,855 & Valid \\
\hline & & $\mathrm{X}_{2.3}$ & 0,732 & Valid \\
\hline & & $\mathrm{X}_{2.4}$ & 0,853 & Valid \\
\hline \multirow[t]{5}{*}{3.} & Lingkungan Keluarga $\left(\mathrm{X}_{3}\right)$ & $\mathrm{X}_{3.1}$ & 0,781 & Valid \\
\hline & & $\mathrm{X}_{3.2}$ & 0,879 & Valid \\
\hline & & $\mathrm{X}_{3.3}$ & 0,743 & Valid \\
\hline & & $\mathrm{X}_{3.4}$ & 0,771 & Valid \\
\hline & & $\mathrm{X}_{3.5}$ & 0,805 & Valid \\
\hline \multirow[t]{5}{*}{4.} & Niat Berwirausaha (Y) & $\mathrm{Y}_{1.1}$ & 0,829 & Valid \\
\hline & & $\mathrm{Y}_{1.2}$ & 0,740 & Valid \\
\hline & & $\mathrm{Y}_{1.3}$ & 0,760 & Valid \\
\hline & & $Y_{1.4}$ & 0,822 & Valid \\
\hline & & $\mathrm{Y}_{1.4}$ & 0,822 & Valid \\
\hline
\end{tabular}

Sumber; Data diolah, 2019

Pengujian realibilitas menunjukan sejauh mana alat pengukur dapat dipercaya atau dapat diandalkan. Pengujian reliabilitas instrumen penelitian dilakukan dengan melihat nilai Cronbach's Alpha dari masing-masing variabel penelitian. Instrumen dikatakan reliabel apabila koefisien Cronbach's Alpha $\geq 0,6$. Hasil uji reliabilitas instrumen penelitian ditampilkan pada Tabel 4.

Table 5.

Hasil Uji Reliabilitas

\begin{tabular}{clcc}
\hline No. & \multicolumn{1}{c}{ Variabel } & Cornbach's Alpha & Keterangan \\
\hline 1. & Motivasi Berwirausaha $\left(\mathrm{X}_{1}\right)$ & 0,865 & Reliabel \\
2. & Locus of Control $\left(\mathrm{X}_{2}\right)$ & 0,853 & Reliabel \\
3. & Lingkungan Keluarga $\left(\mathrm{X}_{3}\right)$ & 0,855 & Reliabel \\
4. & Niat Berwirausaha $(\mathrm{Y})$ & 0,796 & Reliabel \\
\hline Sumber: & Data diolah 2019
\end{tabular}

Hasil uji reliabilitas yang disajikan dalam Tabel 5. menunjukkan bahwa seluruh instrument penelitian memiliki koefisien cronbach's alpha lebih dari 0,60. Hal ini dapat dikatakan bahwa semua instrument reliabel sehingga dapat digunakan untuk penelitian.

Metode regresi linier berganda digunakan dalam penelitian ini untuk mengetahui pengaruh motivasi berwirausaha $\left(\mathrm{X}_{1}\right)$, locus of control $\left(\mathrm{X}_{2}\right)$, lingkungan keluarga $\left(\mathrm{X}_{3}\right)$, dan niat berwirausaha $(\mathrm{Y})$. Pengaruh variable bebas terhadap variabel terikat diuji dengan tingkat kepercayaan $95 \%$ atau $\alpha=5$ persen. Metode ini diuji dengan aplikasi SPSS diperoleh hasil analisis linier berganda sebagai berikut. 
Tabel 6.

Hasil Analisis Regresi Linier Berganda

\begin{tabular}{|c|c|c|c|c|c|}
\hline \multirow[t]{2}{*}{ Model } & \multicolumn{2}{|c|}{$\begin{array}{l}\text { Unstandardized } \\
\text { Coefficients }\end{array}$} & \multirow{2}{*}{$\begin{array}{c}\text { Standardized } \\
\text { Coefficients } \\
\text { Beta } \\
\end{array}$} & \multirow[t]{2}{*}{$\mathbf{t}$} & \multirow[t]{2}{*}{ Sig. } \\
\hline & B & Std. Error & & & \\
\hline (constant) & 0.524 & 0.125 & & 4.201 & 0.000 \\
\hline Motivasi & 0.564 & 0.045 & 0.608 & 12.617 & 0.000 \\
\hline LOC & 0.114 & 0.039 & 0.127 & 2.964 & 0.003 \\
\hline Lingk. keluarga & 0.219 & 0.044 & 0.246 & 5.010 & 0.000 \\
\hline
\end{tabular}

Sumber: Data diolah, 2019

Berdasarkan hasil analisis regresi linier berganda seperti yang ditunjukan pada Tabel 6, maka persamaan regresinya adalah sebagai berikut.

$$
\mathrm{Y}=0,524+0,608 \mathrm{X}_{1}+0,127 \mathrm{X}_{2}+0,246 \mathrm{X}_{3}+\mathcal{E}
$$

Nilai koefisien regresi motivasi berwirausaha $\left(X_{1}\right)$ sebesar 0,608 memiliki arti motivasi berwirausaha berpengaruh positif terhadap niat berwirausaha (Y). Dengan signifikasi $\mathrm{X}_{1}$ lebih kecil dari 0,05 $(0,000<0,05)$. Nilai koefisien regresi locus of control $\left(\mathrm{X}_{2}\right)$ sebesar 0,127 memiliki arti locus of control berpengaruh positif terhadap niat berwirausaha (Y). Dengan signifikasi lebih kecil dari 0,05 $(0,003<$ $0,05)$. Nilai koefisien regresi lingkungan keluarga $\left(\mathrm{X}_{3}\right)$ sebesar 0,246 memiliki arti lingkungan keluarga berpengaruh positif terhadap niat berwirausaha (Y). Dengan signifikasi signifikasi lebih kecil dari $0,05(0,000<0,05)$.

Untuk menguji apakah data yang digunakan normal atau tidak dapat dilakukan dengan menggunakan Uji Kolmogorov-Smirnov dengan melihat nilai Asymp. Sig. (2-tailed). Jika nilai Asymp. Sig. (2-tailed) lebih besar taraf signifikansi yang ditetapkan yaitu 5 persen $(0,05)$, maka data telah berdistribusi normal. Berdasarkan hasil olah data, maka hasil uji normalitas disajikan pada Tabel 6 sebagai berikut.

Tabel 7.

Hasil Uji Normalitas

\begin{tabular}{cc}
\hline & Unstandardized Residual \\
\hline N & 207 \\
Kolmogorov-Smirnov Z & 1,219 \\
Asymp. Sig. (2-tailed). & 0,102 \\
\hline
\end{tabular}

Sumber: Data primer, 2019

Berdasarkan Tabel 7. dapat diketahui bahwa asymp.Sig (2-tailed). Sebesar 0,102 yaitu lebih besar dari 0,05 $(0,102>0,05)$. Dengan demikian data tersebut dinyatakan berdistribusi normal.

Untuk mendeteksi ada atau tidaknya multikolinearitas dalam model regresi yaitu mempunyai angka Tolerance $>0,10$ atau mempunyai nilai VIF $<10$. Berdasarkan hasil analisis, dapat dilihat bahwa koefisien Toleance semua variabel lebih besar dari 0,10 dan nilai VIF yang lebih kecil dari 10. Hasil ini mengindikasikan bahwa tidak terdapat gejala multikolinearitas dari model regresi yang dibuat sehingga pada model regresi ditemukan korelasi antara variabel bebas. Berdasarkan hasil olah data, maka hasil uji multikolinearitas disajikan pada Tabel 8 sebagai berikut. 
Tabel 8.

Hasil Uji Multikolinearitas

\begin{tabular}{lcc}
\hline \multicolumn{1}{c}{ Model } & \multicolumn{2}{c}{ Colinearity Statistic } \\
& Tolerance & VIF \\
\hline Motivasi Berwirausaha $\left(\mathrm{X}_{1}\right)$ & 0,380 & 2,633 \\
Locus of Control $\left(\mathrm{X}_{2}\right)$ & 0,478 & 2,091 \\
Lingkungan Keluarga $\left(\mathrm{X}_{3}\right)$ & 0,367 & 2,724 \\
\hline Sumber: Data primer, 2019 & \multicolumn{2}{c}{}
\end{tabular}

Tabel 8. menunjukkan nilai tolerance dan VIF variable motivasi berwirausaha, locus of control, dan lingkungan keluarga. Berdasarkan hasil analisis, dapat dilihat bahwa koefisien tolerance semua variable lebih besar dari 0,10 dan nilai VIF lebih kecil dari 10. Hasil ini mengindikasikan bahwa tidak terdapat gejala multikolinearitas.

Untuk mengetahui ada atau tidaknya heteroskedastisitas yaitu dengan melakukan Uji Glejser dengan meregresi nilai absolut terhadap variabel independen, dengan ketentuan jika nilai signifikan di atas 0,05 maka memiliki arti tidak terjadi heteroskedastisitas.

Tabel 9.

Hasil Uji Heteroskedastisitas

\begin{tabular}{lcc}
\hline \multicolumn{1}{c}{ Model } & T & Sig. \\
\hline Motivasi berwirausaha & 0,559 & 0,576 \\
Locus of Control & $-1,546$ & 0,124 \\
Lingkungan keluarga & 0,341 & 0,733 \\
\hline
\end{tabular}

Sumber: Data primer, 2019

Tabel 9. menunjukkan bahwa nilai Sig. variable motivasi berwirausaha, locus of control, dan lingkungan keluarga lebih dari 0,05 yang artinya model regresi bebas dari gejala heteroskedastisitas.

Koefisien determinasi ( $R$ Square) berguna untuk mengukur besarnya kontribusi variabel bebas (motivasi berwirausaha, locus of control, lingkungan keluarga) terhadap variabel terikat (niat berwirausaha).

Tabel 10.

Hasil Analisis Koefisien Determinasi $\left(\mathbf{R}^{2}\right)$

\begin{tabular}{cccc}
\hline $\mathbf{R}$ & R Square & Adjusted R Square & Std. Error of the Estimate \\
\hline $0,906^{\mathrm{a}}$ & 0,821 & 0,818 & 0,24785 \\
\hline Sumber: Data primer, 2019 & &
\end{tabular}

Berdasarkan hasil uji pada Tabel 10. nilai $R$ Square sebesar 0,821. Sehingga dapat dihitung persentase kontribusi motivasi berwirausaha, locus of control, lingkungan keluarga terhadap niat berwirausaha sebesar $0,821 \times 100$ persen $=$ $82,1 \%$ persen dan sisanya 17,9 persen dipengaruhi oleh variabel lain diluar penelitian.

Uji F digunakan untuk menguji apakah variabel-variabel independen secara bersama-sama berpengaruh terhadap variabel dependen. Ketentuan yang baik untuk digunakan sebagai model regresi adalah jika sig.t $<0,05$. Hasil uji kelayakan model penelitian ini ditunjukan pada Tabel 11. 
Tabel 11.

Hasil Uji F (Uji Kelayakan Model)

\begin{tabular}{lccccc}
\hline \multicolumn{1}{c}{ Model } & $\begin{array}{c}\text { Sum of } \\
\text { squares }\end{array}$ & Df & $\begin{array}{c}\text { Mean } \\
\text { square }\end{array}$ & F & Sig. \\
\hline Regression & 57.095 & 3 & 19.032 & 309.802 & $.000^{\mathrm{a}}$ \\
Residual & 12.471 & 203 & 0.061 & & \\
Total & 69.566 & 206 & & & \\
Sumber: Data diolah, 2019 & & & &
\end{tabular}

Tabel 11. menunjukkan nilai sig sebesar 0,000 yang lebih kecil dari 0,05 (sig $<\alpha$ ) yang berarti variabel bebas yaitu motivasi berwirausaha $\left(\mathrm{X}_{1}\right)$, locus of control $\left(\mathrm{X}_{2}\right)$, lingkungan keluarga $\left(\mathrm{X}_{3}\right)$ berpengaruh signifikan secara serempak atau bersama-sama terhadap variabel terikat yaitu niat berwirausaha (Y), sehingga penelitian ini dapat dikatakan memenuhi uji kelayakan model atau model penelitian ini dinyatakan layak digunakan sebagai model regresi.

Berdasarkan hasil regresi linier berganda pada Tabel 6 diketahui bahwa nilai koefisien beta variabel motivasi berwirausaha bernilai positif yakni 0,608 dengan nilai sig sebesar 0,000 . Nilai Sig. $0,000<0,05$ mengindikasikan bahwa $\mathrm{H}_{1}$ diterima. Dengan kata lain motivasi berwirausaha berpengaruh positif signifikan terhadap niat berwirausaha.

Berdasarkan hasil regresi linier berganda pada Tabel 6 diketahui bahwa nilai koefisien beta variabel locus of control bernilai positif yakni 0,127 dengan nilai sig sebesar 0,003. Nilai Sig. 0,003 <0,05 mengindikasikan bahwa $\mathrm{H}_{1}$ diterima. Dengan kata lain locus of control berpengaruh positif signifikan terhadap niat berwirausaha.

Berdasarkan hasil regresi linier berganda pada Tabel 6 diketahui bahwa nilai koefisien beta variabel lingkungan keluarga bernilai positif yakni 0,246 dengan nilai sig sebesar 0,000. Nilai Sig. $0,000<0,05$ mengindikasikan bahwa $\mathrm{H}_{1}$ diterima. Dengan kata lain lingkungan keluarga berpengaruh positif signifikan terhadap niat berwirausaha.

Berdasarkan pengujian hipotesis variabel motivasi berwirausaha terhadap niat berwirausaha menyatakan bahwa dalam penelitian ini mendapatkan hasil $\mathrm{H}_{0}$ ditolak dan $\mathrm{H}_{1}$ diterima. Hasil ini mempunyai arti bahwa motivasi berwirausaha berpengaruh positif dan signifikan terhadap niat berwirausaha, ini berarti bahwa semakin tinggi motivasi yang dirasakan maka semakin timggi juga niat berwirausaha. Niat berwirausaha sebagian besar disebabkan oleh mahasiswa yang berorientasi terhadap masa depan dan adanya jiwa kepemimpinan pada mahasiswa. Motivas berwirausaha perlu ditingkatkan lagi agar lebih banyak lagi mahasiswa Universitas Udayana yang menjadi wirausaha. Hasil ini didukung oleh penelitain yang dilakukan oleh Aldino (2011) yang dilakukan di Universitas Andalas Padang, Kumalasari (2013) yang dilakukan di SMK Negeri 4 Purworejo, Owaseni (2014) yang dilakukan di Ajayi Crowther University yang menyatakan bahwa motivasi berwirausaha berpengaruh positif dan signifikan terhadap niat berwirausaha. Hasil ini juga didiukung penelitian yang dilakukan oleh Farouk et al. (2014) yang dilakukan di University of Sfax Tunisia, Kusuma \& Warmika (2016) yang dilakukan di Fakultas Ekonomi dan Bisnis Unud menyatakan bahwa motivasi berwirausaha berpengaruh positif dan signifikan terhadap niat berwirausaha. 
Berdasarkan pengujian hipotesis variabel locus of control terhadap niat berwirausaha menyatakan bahwa dalam penelitian ini mendapatkan hasil $\mathrm{H}_{0}$ ditolak dan $\mathrm{H}_{1}$ diterima. Hasil ini mempunyai arti bahwa locus of control berpengaruh positif dan signifikan terhadap niat berwirausaha ini berarti bahwa semakin tinggi locus of control yang dirasakan mahasiswa maka semakin tinggi niat untuk berwirausaha. Dalam hal ini, niat berwirausaha sebagian besar disebabkan oleh yakin bahwa segala hasil yang dicapai dan keberhasilan yang terjadi disebabkan oleh diri mahasiswa itu sendiri. Sebaiknya locus of control mahasiswa perlu ditingkatkan lagi agar semakin banyak mahasiwa Universitas Udayana yang menjadi wirausaha. Penelitian ini sesuai dengan penelitian yang dilakukan oleh Dinis et al. (2013) yang melakukan penelitian pada mahasiswa di University of Beira Interior Portugal, Ayodele (2013) yang melakukan penelitian di Ilhsan University Nigeria, Uddin \& Bose (2012) yang melakukan penelitian pada mahasiswa di Bangladesh yang menyatakan bahwa locus of control berpengaruh positif dan signifikan terhadap niat berwirausaha. Hasil ini juga didukung penelitian yang dilakukan oleh Adnyana \& Purnami (2016) yang melakukan penelitian di Fakultas Ekonomi dan Bisnis Unud, Bustan (2014) yang melakukan penelitian pada mahasiswa Politeknik Sriwijaya yang menyatakan bahwa locus of control.

Berdasarkan pengujian hipotesis variabel lingkungan keluarga terhadap niat berwirausaha menyatakan bahwa dalam penelitian ini mendapatkan hasil $\mathrm{H}_{0}$ ditolak dan $\mathrm{H}_{1}$ diterima. Hasil ini mempunyai arti bahwa lingkungan keluarga berpengaruh positif dan signifikan terhadap niat berwirausaha ini berarti bahwa semakin tinggi dukungan keluarga untuk berwirausaha maka semakin tinggi niat mahasiswa untuk berwirausaha. Dalam hal ini, niat berwirausaha sebagian besar disebabkan oleh dukungan keluarga dan latar belakang keluarga dari mahasiswa. Penelitian ini sesuai dengan penelitian yang dilakukan oleh Suharti \& Sirine (2011) yang melakukan penelitian pada mahasiswa Universitas Kristen Satya Wacana Salatiga, Sarwoko (2011) yang melakukan penelitian pada mahasiswa Universitas Kanjuruhan Malang, Rasyid (2015) yang melakukan penelitian pada mahasiswa University of YAPIS yang menyatakan bahwa lingkungan keluarga berpengaruh positif dan signifikan terhadap niat berwirausaha. Hasil ini juga didukung penelitian yang dilakukan Ardiyani \& Kusuma (2016) yang melakukan penelitian pada mahasiswa S1 Fakultas Ekonomi dan Bisnis Unud, Hutagalung et al. (2017)yang melakukan penelitian pada mahasiswa University of Malaya yang menyatakan bahwa lingkungan keluarga berpengaruh positif dan signifikan terhadap niat berwirausaha.

Hasil penelitian ini memiliki implikasi teoritis dan praktis. Secara teoritis penelitian ini menunjukan bahwa motivasi berwirausaha, locus of control, dan lingkungan keluarga berpengaruh positif dan signifikan terhadap niat berwirausaha. Dengan demikian hasil penelitian ini memberikan dukungan empiris dan dapat dinyatakan memperkuat hasil-hasil studi terdahulu. Secara praktis penelitian ini diharapkan dapat menjadi bahan pertimbangan dan informasi kepada mahasiswa yang berniat untuk memiliki usaha maupun mahasiswa yang sudah mempunyai usaha. 


\section{SIMPULAN}

Motivasi berwirausaha berpengaruh positif dan signifikan terhadap niat berwirausaha. Hal ini menunjukkan bahwa semakin tinggi motivasi untuk berwirausaha maka niat berwirausaha juga akan semakin meningkat Pengendalian diri berpengaruh positif dan signifikan terhadap niat berwirausaha. Hal ini menunjukkan bahwa semakin tinggi locus of control maka niat berwirausaha juga akan semakin meningkat. Lingkungan keluarga berpengaruh positif dan signifikan terhadap niat berwirausaha. Hal ini menunjukkan bahwa semakin tinggi dukungan keluarga untuk menjadi wirausaha maka niat berwirausaha juga akan semakin meningkat. Untuk meningkatkan kreativitas, inovatif dan jiwa kepemimpinan menjadi wirausaha dapat dilakukan dengan mengikuti seminar kewirausahaan agar dapat memberikan pandangan yang lebih luas tentang kewirausahaan sehingga mahasiswa mampu melihat kesempatan dan peluang bisnis apa saja di zaman sekarang. Cara lain untuk meningkatkan kreativitas, inovatif dan jiwa kepemimpinan bisa juga dengan membeli buku-buku tentang bisnis atau buku-buku tentang kepemimpinan agar menjadi percaya diri untuk membangun dan menjadi pemimpin di usahanya sendiri.

Lingkungan keluarga juga sangat penting dalam meningkatkan niat untuk berwirausaha. Pada indikator kreatifitas orang tua mendapatkan rata-rata terendah maka ada baiknya orang tua juga memberikan masukan tentang wirausaha berupa ide-ide bisnis serta memberikan motivasi untuk anak-anaknya agar menjadi semangat dalam berbisnis.

\section{REFERENSI}

Adnyana, I.G.L.A. \& Purnami, N.M. 2016. Pengaruh Pendidikan Kewirausahaan, Self Efficacy dan Locus of Control Pada Niat Berwirausaha. E-Jurnal Manajemen, 5(2), 1160-1188

Aidha, Z. 2016. Pengaruh Motivasi Terhadap Minat Berwirausaha Mahasiswa Fakultas Kesehatan Masyarakat Universitas Islam Negeri Sumatera Utara. JUMANTIK (Jurnal Ilmiah Penelitian Kesehatan), 1(1): 42-59.

Aldino, F.R. 2011. Pengaruh Motivasi, Self Efficacy Dan Locus Of Control (LOC) Terhadap Minat Berwirausaha (Studi Pada Siswa SMK Kota Padang). EJournal Universitas Andalas Padang, 5(7): 120-139.

Ardiyani, N.P.P. \& Kusuma, A.A.G.A.A. 2016. Pengaruh sikap, pendidikan dan lingkungan keluarga terhadap minat berwirausaha. E-Jurnal Manajemen, 5(8), 5155-5183.

Ayodele, K.O. 2013. Demographics, entrepreneurial self-efficacy and locus of control as determinants of adolescents' entrepreneurial intention in Ogun State, Nigeria. European Journal of Business and Social Sciences, 1(12): 5967. 
Azwar, B. 2013. Analisis Faktor-faktor yang Mempengaruhi Niat Kewirausahaan (Entrepreneurial Intention)(Studi Terhadap Mahasiswa Universitas Islam Negeri SUSKA Riau). Menara, 12(1): 12-22.

Badan Pusat Statistik 2019. Data Jumlah Penduduk Indonesia Tahun 2019. Bali. Baum, J.R., Frese, M. \& Baron., R.A. 2007. The Psychology of Entrepreneurship. Mahwah, New Jersey: Lawrence Erlbaum Publishers.

Bustan, J. 2014. Pengaruh Prestasi, Locus of Control, Resiko, Toleransi Ambiguitas, Percaya Diri, dan Inovasi Terhadap Minat Berwirausaha Mahasiswa. ORASI BISNIS, 11(1), 60-67.

Chimucheka, T. 2013. The impact of entrepreneurship education on the establishment and survival of small, micro and medium enterprises (SMMEs). Journal of Economics, 4(2): 157-168.

Dewi, A.V. \& Mulyatiningsih, E. 2013. Pengaruh Pengalaman Pendidikan Kewirausahaan dan Keterampilan Kejuruan terhadap Motivasi Berwirausaha Siswa. Jurnal. Universitas Negeri Yogyakarta, 3(2): 231-240.

Dinis, A., do Paco, A., Ferreira, J., Raposo, M. \& Gouveia Rodrigues, R. 2013. Psychological characteristics and entrepreneurial intentions among secondary students. Education+ Training, 55(8/9): 763-780.

Direktori Mahasiswa Wirausaha Universitas Udayana 2018. Daftar Wirausaha Muda Universitas Udayana Tahun 2018.

Farouk, A., Ikram, A. \& Sami, B. 2014. The influence of individual factors on the entrepreneurial intention. International Journal of Managing Value and Supply Chains, 5(4): 47.

Gallyn, D.M. 2011. Faktor-faktor yang mempengaruhi Minat Berwirausaha Mahasiswa Universitas Indonesia. Universitas Indonesia.

Habaragoda, B.S. 2013. Exploring the impact of psychological characteristics on entrepreneurial inclination: a study of management undergraduates' inclination toward entrepreneurship in Sri Lankan universities. International Journal of Education and Research, 1(4): 1-10.

Hisrich, R.D., Peters, M.P. \& Shepherd, D.A. 2008. Kewirausahaan Edisi 7. Edisi Bahasa Indonesia. Jakarta: Salemba Empat.

Hutagalung, B., Dalimunthe, D.M.J., Pambudi, A.Q.H. \& Muda, I. 2017. The effect of enterpreneurship education and family environment towards students' entrepreneurial motivation. International Journal of Economic Research, 14(20): 331-348. 
Kasmir 2010. Kewirausahaan. Jakarta: Rajawali Pers.

Kumalasari, K. 2013. Pengaruh Motivasi dan Hasil Belajar Kewirausahaan terhadap Minat Berwirausaha Siswa Kelas XII di Smk Negeri 4 Purworejo. Oikonomia: Jurnal Pendidikan Ekonomi, 2(2), 121-126.

Kustini 2005. Pengaruh Locus of Control, Orientasi Tujuan Pembelajaran dan Lingkungan Kerja Terhadap Self Efficacy dan Transfer Pelatihan Karyawan PT. Telkom Kandatel Surabaya Timur. Tersedia di http://www.damandiri.or.id.

Kusuma, W.A. \& Warmika, K. 2016. Analisis Faktor-Faktor Yang Mempengaruhi Intensi Berwirausaha pada Mahasiswa S1 FEB UNUD. E-Jurnal Manajemen, 5(1), 678-705.

Lestari, R.B. \& Wijaya, T. 2012. Pengaruh Pendidikan Kewirausahaan Terhadap Minat Berwirausaha Mahasiswa di STIE MDP, STMIK MDP, dan STIE MUSI. Forum Bisnis Dan Kewirausahaan Jurnal Ilmiah STIE MDP. STIE MDP, 1(2) hal.112-119.

McClelland, D.C. 1965. N achievement and entrepreneurship: A longitudinal study. Journal of personality and Social Psychology, 1(4): 389.

Mustofa, M.A. 2014. Pengaruh pengetahuan kewirausahaan, self efficacy, dan karakter wirausaha terhadap minat berwirausaha pada siswa kelas XI SMK Negeri 1 Depok Kabupaten Sleman. Skripsi. Yogyakarta: Universitas Negeri Yogyakarta.

Myers, D.G. \& Spencer, S.J. 2013. Social Psychology Canadian Edition. New York: McGraw-Hill.

Nursito, S. \& Jati, A.S.N. 2013. Analisis Pengaruh Interaksi Pengetahuan Kewirausahaan Dan Efikasi Diri Terhadap Intensi Kewirausahaan. Kiat bisnis, $5(3)$.

Ogunleye, A.J. \& Osagu, J.C. 2014. Self-efficacy, tolerance for ambiguity and need for achievement as predictors of entrepreneurial orientation among entrepreneurs in Ekiti state, Nigeria. European Journal of Business and Management, 6(17): 240-250.

Owoseni, O.O. 2014. The influence of some personality factors on entrepreneurial intentions. International Journal of Business and Social Science, 5(1), 278284.

Praswati, A.N. 2014. Analisis faktor-faktor yang mempengaruhi minat wirausaha 
di kalangan mahasiswa studi kasus: fakultas ekonomi dan bisnis universitas muhammadiyah Surakarta. Jurnal Seminar Nasional dan Call for Paper, 4(1), 280-302.

Pujiastuti, E.E. 2013. Pengaruh kepribadian dan lingkungan terhadap intensi berwirausaha pada usia dewasa awal. Asian Journal of Innovation and Entrepreneurship, 2(1): 1-8.

Ramayah, T. \& Harun, Z. 2005. Entrepreneurial intention among the student of Universiti Sains Malaysia (USM). International Journal of Management and Entrepreneurship, 1(1): 8-20.

Rasli, A., Khan, S.U.R., Malekifar, S. \& Jabeen, S. 2013. Factors affecting entrepreneurial intention among graduate students of Universiti Teknologi Malaysia. International Journal of Business and Social Science, 4(2), pp: 182188.

Rasyid, A. 2015. Effects of ownership structure, capital structure, profitability and company's growth towards firm value. International Journal of Business and Management Invention, 4(4): 25-31.

Robbins, S.P. \& Judge, T.A. 2007. Perilaku organisasi. 10 ed. Jakarta: PT Indeks Kelompok Gramedia.

Rotter, J.B. 1969. Generalised expectations for internal versus external control of reinforcemen. Psychological Monographs, 80(1): 169-214.

Saiman, L. 2009. Kewirausahaan: Teori, praktik, dan kasus-kasus. Jakarta: Salemba Empat.

Sarwoko, E. 2011. Kajian empiris entrepreneur intention mahasiswa. Jurnal ekonomi bisnis, 16(2): 126-135.

Silvia, S. 2013. Pengaruh Entrepreneurial Traits dan Entrepreneurial Skills terhadap Intensi Kewirausahaan (Studi Empiris Dampak Pendidikan Kewirausahaan pada Mahasiswa Universitas Kristen Petra, Surabaya). Agora, 1(1): 404-410.

Slameto 2010. Belajar dan Faktor-faktor yang Mempengaruhinya. Jakarta: Rineka Cipta.

Suharti, L. \& Sirine, H. 2011. Faktor-faktor yang berpengaruh terhadap niat kewirausahaan (entrepreneurial intention). Jurnal manajemen dan kewirausahaan, 13(2): 124-134.

Suryana 2008. Kewirausahaan. Jakarta: Salemba empat.

Tama, A.A. 2010. Analisis Faktor-Faktor yang Memotivasi Mahasiswa yang 
Berkeinginan menjadi Entrepeneur. E-Jurnal Universitas Diponegoro, 5(2), 207-218.

Uddin, M.R. \& Bose, T.K. 2012. Determinants of entrepreneurial intention of business students in Bangladesh. International Journal of Business and Management, 7(24): 128.

Venesaar, U., Kolbre, E. \& Piliste, T. 2016. Students' attitudes and intentions toward entrepreneurship at Tallinn University of Technology. TUTWPE, 154(1), 97-114.

Wardoyo 2012. Pengaruh Pendidikan Dan Karakteristik Kewirausahaan Terhadap Intensi Berwirausaha Mahasiswa Pada Perguruan Tinggi Swasta Di Jakarta. Jurnal Bisnis, 2(1), 222-230.

Wijaya, U.T. \& Tanumihardja, J.E. 2014. Pengaruh Pengetahuan Kewirausahaan dan Konsep Diri terhadap Minat Berwirausaha. Jurnal Pendidikan Vokasional Teknik Mesin, 2(2): 79-86.

Wiriani, W., Piatrini, P.S., Ardana, K. \& Juliarsa, G. 2013. Efek Moderasi Locus Of Control Pada Hubungan Pelatihan Dan Kinerja Pada Bank Perkreditan Rakyat Di Kabupaten Badung. Jurnal Ilmiah Akuntansi dan Bisnis, 8(2): 99105. 